\title{
INTEGRATING ISLAMIC PRINCIPLES AND VALUES INTO THE FABRIC OF GOVERNANCE
}

\author{
Daud AbdulFattah Batchelor
}

\begin{abstract}
Important Islamic principles and values in governance are identified from the Qur'an, Sunna and the essential Shariah objectives (Maqasid alSharicah). The principles (vicegerency, rule of law, justice, social welfare, separation of powers, accountability, consultation, obedience, public participation, inclusiveness, equality, dignity, hisbah or enjoining the good and forbidding the evil, limiting money politics, and ensuring a free, independent media, and peace and security) have considerable bearing on the structure of government institutions and in ensuring good governance, while the values (trustworthiness, transparency, cooperation towards good, moderation, eagerness for knowledge, frugality and valuing time, and good neighbourliness) relate more to the moral qualities required by rulers, leaders and government officers alike. The proposed process of integrating these into governance is based on a systems thinking approach which acknowledges that governance works in a systemic framework. It also stresses the modern discipline of change management but points out that both it and a systems approach were already applied most successfully by Prophet Muhammad [pbuh]. Working examples, which can be adapted for use in Muslim countries for government departments and civic society have been identified from Canada and Malaysia, respectively.
\end{abstract}

\section{Introduction}

An Islamic system of governance per se is an 'ideal' system, which is a tantalising objective for Muslims but not always easily achievable in practice. Countries may call themselves "Islamic" but Islamic values may not have strongly penetrated the consciousness of their leaders and citizens. Following the colonial era and with widespread Islamic education, Muslims worldwide are exhibiting a renaissance of interest in the implementation of Islamic principles and values in their political systems. In the West following the global financial crisis and collapse of major corporations attributed to poor ethical financial practices, there has been a strong parallel trend towards incorporating ethics and values into governance.

There has been a belief that by emphasising basic Islamic teachings Islamic values would naturally be transferred to the public arena and to government institutions. This however, has not necessarily been the case. Muslims in Afghanistan and West African countries for example, exhibit the highest level of observance of religious rituals in surveyed countries but also experience amongst the highest incidences of perceived corruption. ${ }^{1}$

From another perspective, a key failure of the mujāhìdin parties in Afghanistan, who defeated the powerful Soviet armed forces, while standing on a platform of 
striving towards an Islamic political order, was their inability to transfer Islamic values. Analyst Olivier Roy, pointed to a general deficiency with their Islamism but erred in oversimplifying that "Islam does not offer a blueprint of an Islamic government but just promotes Islamic values"2. These examples however, illustrate the need for a planned administrative system and institutions ${ }^{3}$ whereby Islamic values can be effectively integrated. It would be inspired by the examples of Prophet Muhammad [pbuh] and the Rightly Guided successors who established the first Islamic polity in Medina that represented the "best community raised for the benefit of mankind"4.

An effective approach for integrating Islamic principles and values into government will need to be comprehensive and holistic. Some tools developed by western practitioners based on older, partly Islamic concepts, can be applied. Islamisation involves change. Change management $t^{5}$ needs to address the System ${ }^{6}$ in which it operates; then to apply effective strategies to bring about sustainable changes by understanding its component parts and how they operate. A System is a set of interdependent, interacting components with mutual relationships forming an integrated complex whole - as well as the rules that govern their interactions. Human organisations are viewed as conceptual systems. A system of government is a coordinated body with an organisational scheme to enable effective governance. The system will comprise a body structure developed according to Islamic principles and a 'soul' of government officers and citizens who will ideally be conversant in Islamic values. Applying systems thinking uses a style of reasoning and problem solving that starts by understanding the system properties, including its structural and social and human factors (behavioural aspects) to achieve a successful outcome. Such an approach will help practitioners to see how to change systems effectively and to act in tune with the natural processes of the real world.

The process of integrating Islamic principles and values into the fabric of governance involves the following steps:

- Identifying the key Islamic principles and the government institutions that reflect them.

- Identifying the Islamic values to be inculcated.

- Outlining the key aspects of social transformation.

- Determining the approach for transforming government through change management.

- Routinely applying the concept of Ihsān or continual improvement through reviews and audits.

"Governance" is the act of governing or ruling whereas "government" is the body of representatives and institutions through which this is done. The key Islamic 
principles and their allied institutions will be first discussed below, followed by an elaboration of the important Islamic values.

\section{Islamic Principles}

Islamic principles provide the foundation for Islamic governance. The primary Islamic doctrine is Tawhìd (Belief in the Absolute Unity of God) ${ }^{7}$ on which all Islamic institutions should be established. It may be stated at the outset that whatever is the common heritage of mankind and is beneficial can be adopted in Islamic governance. Many government institutions in their modern form have developed in non-Muslim countries in the absence of any obvious contradiction to Shariah and may be accepted in an Islamic system based on the Islamic legal principle that what is not specifically prohibited is potentially acceptable ${ }^{8}$. 'Modern' institutions in non-Muslim countries often developed socially in response to and in conformance with the natural laws of Allah (sunnat-Allah) and many countries have incorporated religious ethics (from Christianity or Judaism) that are unsurprisingly aligned with Islamic teachings.

Nayef Al-Rodhan had proposed eight criteria for ensuring good governance: (1) participation, equity and inclusiveness (2) rule of law (3) separation of powers (4) a free, independent and responsible media (5) government legitimacy (6) accountability (7) transparency, and (8) limiting the distorting effect of money in politics. ${ }^{9}$ Derivation of these criteria as universal principles can be provided from Islamic sources and are discussed further below. Effective governments have always involved three functional branches - the executive, the legislature and the judiciary.

\section{Sovereignty}

The classical Islamic position based on the Qur'an ${ }^{10}$ is that true sovereignty over a people belongs to Almighty Allah. However, as Allah has provided for mankind on earth to conduct their own affairs, he has instituted the role of khiläfah (successors or vicegerency) for them ${ }^{11}$. The Successor rulers to Prophet Muhammad [peace be upon him] took this title and role, which is in reality a trust (amānah) to uphold God's law, the Shariah ${ }^{12}$. As humans are the khalifah of Allah, the concept exists that the ummah itself is the repository of this trust. It is only through their legal representatives that the ruler (the Executive) can take power with a delegated sovereignty on their behalf.

\section{Leadership and Legitimacy (The Executive)}

In Islam, the role of the executive is paramount in exemplifying the true values to be inculcated within the government. The leader must practice what he says he will do. This is in accordance with the example of Prophet Muhammad 
[pbuh] who practiced principle-centred leadership and embodied all the virtues enunciated in the Holy Qur'an.

The issue of government legitimacy in Islam has become blurred by historical precedent where even the great scholars ${ }^{13}$ accepted or legitimised certain usurpers of power. This was perhaps acceptable in emergency situations shortterm but not as general precepts. A review suggests the main sources of Islamic legitimacy in governance are: (1) A qualified executive candidate (2) freely elected by a majority of citizens or their representatives (3) bay'ah (allegiance by consent) of citizens based on this election (4) the upholding of Shariah law and provision of justice (5) ensuring social support for needy citizens ${ }^{14}(6)$ ruling through consultation $(s h \bar{u} r \bar{a})(7)$ demonstrating transparency and accountability of government, and (8) change of the executive (or government) during periodic elections or due to physical or mental incapacity or failure to perform mandatory ('ibādah) practices in public.

\section{Rule of Law and Justice ('Adl) (The Judiciary)}

Scholars agree that justice is a seminal aspect of the Islamic political system: "Justice is a supreme virtue and it is, in all its manifestations, one of the overriding objectives of Islam to the extent that it stands next in priority to belief in the Oneness of God (tawhìd) and the truth of the Prophethood of Muhammad [pbuh]." 15 This follows from explicit statements of God Almighty, referring to justice both in civic relations, as well as in court rulings ${ }^{16}$ :

Allah does command you ... when you judge between man and man, that you judge with justice (Al-Nisā', 4: 58).

Islam requires that justice transcends considerations of "race, religion, colour and creed"17 even if it disadvantages one's own kin and favours a protagonist. The challenge to perform justice is especially high for a ruler but then the Prophet [pbuh] cited the great reward for a "just ruler" that he would be foremost among those on the Day of Judgement to be protected by the Shade provided by Allah Himself. ${ }^{18}$ Mohammad Hashim Kamali, amongst others, stressed that as envisaged by the Qur'an, including the verse below, justice must be administered under the rule of law ${ }^{19}$, signifying the essential establishment also of a valid authority to implement Shariah law.

If any do fail to judge by (the light of) what Allah has revealed, they are (no better than) Unbelievers (Al-Mā'idah, 5: 44).

\section{Social Justice}

A ruler or government must strive to secure the people's welfare (mașlahah) in accordance with the legal maxim that "the Imam's (head of state) performance 
is judged by reference to people's welfare". ${ }^{20}$ This is the single most important criterion by which to evaluate the success or failure of an Islamic government. Consequently, to be Islamic, a State should ensure that "every individual, man and woman, shall enjoy that minimum of material well-being without which there can be no human dignity, no real freedom and, in the last resort, no spiritual progress". ${ }^{21}$ The Prophet [pbuh] ruled that in addition to zakat there is provision in the wealth of the wealthy to support the poor whenever the zakat sum is insufficient to ensure their basic needs:

There is indeed a duty $[h a q]$ on property apart from zakat. ${ }^{22}$

\section{Separation of Powers}

Although Khulafā' ar-Rāshidūn rule in Islam's early history involved the centralisation of powers, there is no Shariah ruling that deters separation of powers between the executive, judicial and legislative branches in an Islamic government today. ${ }^{23}$ Cogent arguments are provided by Kamali necessitating the executive's non-involvement in the general formulation of Shariah rulings by the fuqāha and in the implementation of decisions by the judiciary. Muhammad Asad and Muhammad El-Awwa, amongst others, have also argued that a head of state is obligated to take the majority position of shūra members $^{24}$. Kamali concluded that "the implications of tawhìd need not be extended to the organisational structure of power in the state". Rather a separation of powers is preferred. ${ }^{25}$

\section{Obedience and Loyalty}

Obedience (t $t \bar{a}$ ' $a h)$ to Allah, the Prophet [pbuh] and the legitimate government, is obligatory on believers as indicated by the following Qur'anic verse:

O you who have believed, obey Allah and obey the Messenger and those in authority among you. And if you disagree over anything, refer it to Allah and the Messenger.... That is the best [way] and best in result. (Al-Nisā', 4: 59)

This obedience to rulers is qualified if they become oppressors. The Prophet further stressed obedience to delegates of the legal authority: "Whoever obeys my appointed leader has indeed obeyed me, and whoever disobeys my appointed leader has in fact disobeyed me". ${ }^{26}$ Another duty of citizens next to obedience is

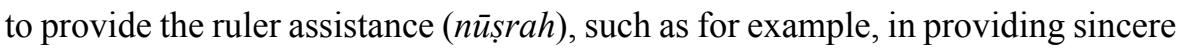
advice (nașīhah). ${ }^{27}$

\section{Accountability (Muhāsabah)}

The government is accountable to the Public for the responsibilities entrusted by them to the leader. Any Islamic-minded leader first needs to assess his own deeds 
(muhāsabah al-nafs) and correct them to ensure his success in the Hereafter in line with the Prophet's [pbuh] instruction:

Every one of you is a guardian and is responsible for his charges: The Imam (ruler) of the people is a guardian and is responsible for his subjects. ${ }^{28}$

Accountability as an Islamic value has been reviewed by Kamali who identified the following premises of accountability in Islamic governance ${ }^{29}$ :

1. Political authority in the Islamic system belongs to the community that elects the head of state;

2. Consultation (mushäwarah) and the right of people to be consulted in government affairs is a principal means by which the community participates in government, voices its concerns on government policy, and takes the government to account;

3. The hisbah principle of promotion of good and prevention of evil and its allied concept of giving sincere advice (nașinhah) also render the government accountable;

4. There is no recognition in Shariah of any exception to the rule of law. Neither the head of state nor government officials are above the law;

5. The community is vested with the right to depose a deviant ruler and government;

6. The citizen's duty to obey ends when the government itself violates the law;

7. Accountability is manifested in the manner of selection, appointment and dismissal of government employees;

8. Trust of governance is predicated in accountability to God Most High and to the community since vicegerency (khiläfah) entrusts the community to establish good government;

9. The right to complain for one who is wronged or becomes a victim of official abuse;

10. Violators are liable for payment of damages, penal sanctions or both; and

11. Bribery and corruption are punishable, and the use of an official position for personal advantage is not tolerated.

\section{Consultation (Shūrā) (The Legislature)}

The conduct of true consultation $(s h \bar{u} r \bar{a})$ on state matters with representatives of the Islamic polity is considered mandatory upon a ruler. ${ }^{30}$ Kamali noted that since the Prophet himself adopted shürā as a regular feature of his leadership and this pattern was followed by the pious Caliphs after him, it has become a normative practice. ${ }^{31}$ There would seem to be close compatibility with modern 
parliamentary systems where deliberations to ensure good decision-making by the Public's representatives take place involving the principles of shūra,$i j m \bar{a}$ ' (consensus) and ijtihād (independent reasoning). The Shariah vests the people's representatives with the authority to pass consensus-based legislation through ijm $\bar{a}$ ' since delegated sovereignty belongs to the ummah. ${ }^{32}$ A legislature can thereby deliberate and pass laws on public affairs which are not covered in the clear $n u s \bar{u} s$ s of the Shariah, but they should be in accordance with maqāșid alsharī ah objectives. Where lay people unqualified in Islamic law are involved in preparing new legislation, qualified fuqaha experts should be provided to assist in the law-making process.

\section{Participation and Inclusiveness}

Kamali emphasised the critical importance of public participation in government, "Islamic government is a qualified democracy in that it holds the community as the locus of authority that can take the government to account and may ultimately depose it." ${ }^{\prime 3}$ The Public may participate through the election of representatives to a parliament. The core Islamic value of the basic equality of mankind indicates there should be equal access for citizens to participate in the government process, which should thereby be inclusive for ethnic and religious minorities.

\section{Equality (Musāwā), Dignity and Mutual Respect (Al-c/rd)}

The following is a decisive statement in the Qur'an on the general equality of mankind with the only valid point of distinction being the level of a person's piety:

O mankind! We created you from a single (pair) of a male and a female, and made you into nations and tribes, that you may know each other. Verily the most honoured of you in the sight of Allah is the most Godconscious of you. (Al-Hujurāt, 49: 13)

The creation by Islam fourteen centuries ago of an egalitarian society was "nothing less than a social revolution". ${ }^{34}$ Although the concept of equality is relative as there is no absolute equality since people are all inherently different, nevertheless in regard to the sphere of transactions with each other (mu' amalät), "the Shariah is affirmative on the equality in basic rights, and the spiritual distinction that some individuals may have over others is not taken into account". 'Equality' of citizens is understood here as: (1) Equality before the law and courts of justice; (2) Equality in employment opportunities; (3) Equality in general duties, such as taxation; and (4) Equality in meeting people's welfare needs. ${ }^{35}$

The following Qur'anic verse depicts dignity as a natural right of every person "regardless of colour, race or religion", which is provided as an expression of God's favour and grace - not just resulting from meritorious conduct. ${ }^{36}$ 
We have bestowed dignity on the progeny of Adam ... and conferred on them special favours above a great part of Our creation. (Al-Isrā', 17:70)

It is a cardinal rule therefore, to be considerate to one another and to recall the Prophet's advice that "Whoever wishes to be delivered from the hell-fire and enter the garden should treat people the way he or she wishes to be treated". ${ }^{37}$

\section{Hisbah (Enjoining Good and Forbidding Evil)}

Hisbah is a broad principle to be undertaken by every qualified citizen in his or her own capacity, as is repeatedly ordained in the Holy Qur'an:

The believers, men and women, are awliya ' '(helpers, protectors) of one another; they enjoin good and forbid evil. (At-Tawbah 9:71)

Hisbah is also an essential feature of Islamic government and a prerequisite for its success:

Allah will certainly aid those who aid His (cause) ... (Those) who, if we establish them in the land, establish regular Prayer and give regular Charity, enjoin the right and forbid wrong. (Al-Hajj, 22:40-41)

The traditional Muhtasib role in Middle Eastern countries encompassed the regulation of trade and commerce in bazaars, overseeing the standards of craftsmen, and the supervision of public morals, public baths, schools, public safety and traffic regulation in conformance with Shariah law. In modern times, the institution has operated successfully in Pakistan and is concerned there mainly with investigating and rectifying injustices faced by the Public from government departments. ${ }^{38}$ Hisbah requires citizens to be vigilant in promoting peace and justice in the community. If necessary, a citizen may resort to criticising the ruling authorities within the limits of proprietary and public interest. ${ }^{39}$ The hisbah concept should also be used to promote ethical business practices. ${ }^{40}$

\section{Free, Independent and Responsive Media}

As each citizen is considered to be a khalifah of Allah, it is essential citizens are well-informed about issues since they are required to make choices on election candidates and be involved as stakeholders to present their views in public forums. For this reason many constitutions of Islamic republics correctly call for a free, independent and responsible media. ${ }^{41}$ Furthermore, after a government is elected, it must be accountable, and so government policies and their implementation need to be reported in a free environment constrained only by the necessity to avoid slander, acrimonious debates, or the release of national secrets.

A form of media control of serious concern is when media moghuls develop a stranglehold over how and what news is portrayed to the public. Such is the 
case of the media conglomerate of Rupert Murdoch, which published falsified information suggesting Iraq held weapons of mass destruction to encourage the 2003 invasion of this Muslim country, with devastating ongoing consequences to its citizens. ${ }^{42}$

The Qur'an is replete with admonishments to respect each other's dignity and to refrain from making false accusations or statements, which disturb good relations between mankind, and to observe good manners in broadcasting news:

O you who believe! If a wicked person comes to you with any news, ascertain the truth lest you harm people unwittingly ... Let not some men among you laugh at others; It may be that the (latter) are better than the (former) ... Nor defame nor be sarcastic to each other by (offensive) nicknames ... Avoid suspicion as much (as possible): for suspicion in some cases is a sin; and spy not on each other, nor speak ill of each other behind their backs. (Al-Hujurāt, 49:6, 11-12)

Mechanisms to thwart biased or incomplete portrayals of important news require legislation to prevent media concentration in a few hands, and to ensure fairness, impartiality and objectivity.

\section{Limiting the Distorting Effect of Money in Politics}

Certain well-placed individuals are often attracted to worldly status for their own sake but their desire becomes insatiable when they wish to amass even greater wealth and power. It is often powerful elites in society who wish to influence decision-makers and the public through their control over the media. Such is frequently the case in the United States. In contrast, Western European countries with their short publicly-funded election campaigns often with free advertising minimise the role of money politics in securing the election of pliable candidates. The abuse of wealth to wrongly influence persons in authority and unlawfully consume another's rizq (provisions) is forbidden in the Holy Qur'an. ${ }^{43}$ Islamic teachings are replete with advice against such tendencies so as to create a healthy society in which all citizens ideally have similar opportunities to progress spiritually and materially.

\section{Ensuring Peace and Security}

An Islamic government is committed to protect the rights of life, ownership, and personal security, which are essential (al-darūriyyāt) Shariah objectives. ${ }^{44}$ Allah rewards those who seek peace and calls against hostilities except against aggressors:

Whoever forgives and makes peace, Allah will reward him for it. Verily God does not love the transgressors. (Ash-Shūrā, 42:40) 
Based on Islamic injunctions Kamali defined the individual's right to personal security in a State as "his right to live a peaceful life without fear of aggression, unlawful arrest, detention and punishment." ${ }^{45}$ Peace and security in Islamic governance is enhanced by building unity among citizens - Muslims and nonMuslims alike - who can be members of one ummah as exemplified in the constitution of the early Madinah state. This unity and concern for each other is the basis for both resistance to external threats as well as in ensuring national harmony.

The Islamic principles discussed above combine in their many facets to help achieve the darüriyyāt (essential) objectives (maqāssid) of the Shariah - the protection of faith, life, intellect, lineage, dignity, and wealth.

\section{Islamic Values}

Islamic values (Table 1) are the prime ethical and moral qualities derived from the revealed texts, which Muslims aspire for their leadership and government to hold and to become inculcated amongst the general Public.

Table 1: Islamic Values in Governance

\begin{tabular}{ll}
\hline \multicolumn{1}{c}{ Islamic Values } & \multicolumn{1}{c}{ Qur'anic References } \\
\hline Trustworthiness & $23: 8-11 ; 4: 6-10,58 ; 8: 27$ \\
Transparency of government (anti-corruption) & $2: 188 ; 4: 29$ \\
Cooperation towards good between citizens & $5: 2$ \\
Moderation; avoiding harshness and difficulty & $2: 143 ; 2: 185 ; 3: 159 ; 4: 28 ; 5: 6 ; 31: 19$ \\
Eagerness to learn and share knowledge & $3: 71 ; 20: 114 ; 30: 56 ; 39: 9 ; 96: 1-5$ \\
Frugality; valuing time and punctuality & $6: 141 ; 7: 31 ; 17: 26-29 ; 103: 1-3$ \\
Good neighbourliness & $4: 36$ \\
\hline
\end{tabular}

\section{Trustworthiness}

Government leaders especially need to be trustworthy and keep their covenants (amānah) as they are directed in the Holy Qur'an. Their office is for the wellbeing of the citizens and the country not for their own personal interests.

Allah does command you to render back your trusts to those whom they are due... (Al-Nisā', 4:58)

\section{Transparency of Government}

This value is concerned with openness and avoiding bribery and corruption, which is unacceptably too common in Muslim societies. Allah decries this vice: 
[D]o not eat up your property among yourselves for vanities, nor use it as bait for judges, with intent that you may eat up wrongfully and knowingly a little of (other) people's property. (Al Baqarah, 2:188)

Prophet Muhammad [pbuh] further emphasised this: "Cursed is the one who bribes and the one who takes a bribe". ${ }^{46}$ Following a comprehensive review, Kamali concluded: "It is forbidden for government officials to accept bribe of any kind, whether in the name of gift, donation or contribution from anyone in the course of duty". ${ }^{47}$

\section{Cooperation towards Good ( $\left.\operatorname{Ta}^{c} \bar{a} w u n\right)$}

A justification for people coming together in a single polity is the benefit obtained from their mutual cooperation for the provision of different services for each other due to their different specialised trades, professions, and competencies, as well as different positive character traits that complement each other and contribute to the well-being of society. God Most High instructs the believers towards this prime value:

Cooperate in righteousness and piety, but do not cooperate in sins and aggression. (Al-Mā'idah, 5:2)

Cooperation in righteousness and piety are the keys to building a taqwa-oriented community of mutual trust, dignity, respect and support.

\section{Moderation (Wasatiyyah) and Avoiding Harshness and Difficulty (Taysīr, Rafc al-Harj)}

Kamali reviewed the following seminal Qur'anic verse and understood its meaning as "The ummah must remain faithful to the commitment to moderation" 48 :

Thus have we made of you, an ummah justly balanced, that you might be witnesses over the nations, and the Messenger a witness over yourselves. (Al-Baqarah, 2:143)

In his recent writings, Kamali recommended the following wasatiyyah approach to governance:

Good governance is a potent instrument and facilitator of moderation and balance in public affairs. Consultative leadership that listens to the voice of its people while remaining alert to extremism and imbalance is indispensible to addressing issues as and when they arise. It is often a question of understanding the people's concerns through good advice, effective communication, receptivity and trust between the people and their leaders. Consultative engagement with experts and community 
leaders as well as effective decision-making mechanisms often facilitate and articulate balanced and comprehensive responses to issues. ${ }^{49}$

Important Islamic values related to wasatiyyah include avoiding the extremes of harshness and of imposing unnecessary difficulties. God Most High advised Prophet Muhammad [pbuh] that:

It is part of the Mercy of Allah that you do deal gently with them. Were you harsh-hearted, they would have broken away from about you: so pass over (their faults). (Al-'Imrān, 3:159)

Another important value is that of facilitating the easier path (taysìr) when alternatives exist and each is permissible, and having similar potential benefit, as indicated in another Qur'anic verse:

[Allah] does not want to put you in difficulties. (Al-Baqarah, 2:185)

The Prophet [pbuh] further clarified this by stating, "The best of your religion is the easier options therein" 50 . In imbuing this value into the government administration, efforts should be made towards alleviating hardship and in facilitating the ease and well-being of citizens.

\section{Knowledge-centredness (Eagerness for $\mathrm{c} / \mathrm{lm}$ )}

The Qur'an is replete with frequent instructions to acquire knowledge - and in providing respect to the Prophets and those imbued with knowledge and wisdom - as indicated in its being the first of its revealed verses ${ }^{51}$, as well as the following:

[S]ay, "O my Lord! Advance me in knowledge.” (T⿱亠̄a Hā ,20:114)

Allah teaches us to respect those who have knowledge in various fields:

Say, "Are those equal, those who know and those who do not know?" (Al-Zumar, 39:9)

Prophet Muhammad [pbuh] said, "Seeking knowledge is a sacred duty imposed on every Muslim man and woman" 52 so the citizenry of the country in toto need to have good education facilities provided for them. Knowledge is essential for good governance - for timely decision-making, for identifying and resolving important issues in society, and for facilitating economic development. However, knowledge that is destructive for mankind, physically, intellectually or spiritually, and promotes alienation, dehumanisation or environmental destruction, must be rejected. ${ }^{53}$

\section{Avoidance of Waste (Israf); Frugality/Cost-Efficiency and Punctuality/Time-Efficiency}

An Islamic government and its public servants need to act as stewards to carefully 
husband the scarce natural and financial resources at their disposal. Further they need to conduct their responsibilities in a timely manner to achieve results within the financial budgets allocated. There should be no wastage of public assets, time or money. The national treasury holds funds in trust for the citizens that should be used wisely. Extravagance of one person leads to deprivation of another and the basic guideline on utilisation of resources and spending is moderation in consumption and spending that avoids both the extremes of niggardliness and extravagance ${ }^{54}$ as is reflected in Allah's directives:

Verily spendthrifts are brothers of the Evil Ones ... Make not your hand tied to your neck, nor stretch it forth to its utmost reach, so that you become blameworthy and destitute. (Al-Isrā , 17:26-29)

This maxim also relates to punctuality and in the observance of time limits:

By Time, verily Man is in loss, except such as have faith and do righteous deeds. (Al- 'Așr, 103:1-3)

These important messages on minimising waste are backed-up by admonitions of the Prophet: "A person will be asked about his life and how he spent it, his youth and how he used it, and his money: how he earned it and how he spent it"

\section{Good Neighbourliness}

God Almighty has called on Muslims to take the utmost care to develop good relations with their neighbours and kin-folk:

Worship Allah and join none with Him; and do good to parents, kinsfolk, orphans, the poor, the neighbour who is near of kin, and the neighbour who is a stranger... (Al-Nis $\bar{a}, 4: 36)$

It could be understood by analogy that an Islamic country should also display this trait in external affairs with neighbouring countries. In this respect, it is instructive to read in the Qur'an that:

Allah forbids you not, with regard to those who fight you not for [your] Faith nor drive you out of your homes, from dealing kindly and justly with them... (Al-Mumtahanah, 60:8)

\section{Social Change - Essential Precursor to Islamic Government}

Change in society first needs to begin with change within the heart and mind of the individual practitioner to reflect the Islamic values, who can then influence change amongst social networks. It can then spread within and beyond the State structures so the institutions are soundly rooted within civil society. To achieve a government inspired by Islamic principles and values requires that a majority of 
citizens support it. Islamic government cannot rightly or practically be imposed by fiat upon people but must be one wherein the public participates and becomes part of the process. This is the lesson provided by the limited success of the Islamising experience of Zia ul-Haq's authoritarian regime in the 1980s in Pakistan:

Islamization "from above" is a risky proposition unless accompanied by Islamization "from below". Effective change cannot simply be mandated or legislated. Societal acceptance is based both upon involvement through representation in the process of change and upon understanding, attitudes and values. ${ }^{56}$

The mass da'wah approach and focus on community welfare of the Muslim Brotherhood in Egypt has arguably been more effective than the elite approach initially taken by the Jama'at-i Islami in Pakistan for Islamising society. Further, the manner of Islamisation to receive public "buy-in" must address real societal needs and be conducted on the basis of Islamic principles:

'Islamisation' measures introduced in Pakistan during the Zia regime became associated with the increasing sectarian tensions because of their emphasis on Shariah laws and fiqhi hair-splitting, rather than on maqāṣid al-Sharīah (Shariah objectives). ... A different Islamic agenda signifying freedom, tolerance and concern for Islamic principles ...

would have enhanced social harmony and national integration. ${ }^{57}$

Social change is a key prerequisite for Islamic government, as was clearly demonstrated by Prophet Muhammad [pbuh] in changing the dominant precursor Arab jähiliyah society to become the "khayrun ummah". Allah indicates that social change begins at the individual level:

Verily, never will Allah change the condition of a people until they change it themselves (with their own souls). (Al-Ra'd, 13:11)

Sumaya Mohamed and Shadiya Baqutayan ${ }^{58}$ described how social change in Islam takes place at three levels - in the individual, the community or ummah, and then the universal level. Individually, the process occurs in stages beginning with Islam, then Faith (Iman) and finally in pristine practices (Ihsān), with the individual represented at each stage as a Muslim, mu'min, and ultimately a muhsin, based on the well-known Jibraili hadith ${ }^{59}$. Societal change then necessarily requires first changes in individuals, which involves both Tazkiyah and Tafakkur. Tazkiyah is 'the effort directed upon oneself for the attainment of moral and religious perfections ${ }^{\prime 60}$ - its locus is the ego or nafs. Islam is replete with a methodology for achieving this change, termed the greater jihad. Change in tandem called Tafakkur, is required in the mindset (' $a q l$ ) of the person to gain 
a true understanding on matters. Positive changes lead in the direction of Ihsān. The individually guided and enlightened Muslims will then wish of their own volition to make $d a^{\prime}$ 'wah (call) and tabligh (preaching) to bring change in others and in societal institutions:

When the Muslims, as individuals, purify their innate and outer nature and perfect themselves both physically and spiritually, they turn to change and improve the social structure of their societies. They start changing the moral behavior of their families, and close associates. They then turn to their group, society and community. All these improvements are accomplished by performing Islāh [reform or striving towards pious action]. [Ultimately, they] change other institutions of their societies such as family, education, economy, and politics, on the basis of Islamic Shariah. ${ }^{61}$

The concept of Isläh or reform is close to that of Tajdìd, which term can be considered to mean renewing the application of Islam to society, such as Islamic principles that have become neglected. ${ }^{62}$ These two activities, IslähTajdid, can go hand in hand, the one strengthening the other to bring about positive societal change.

\section{Integrating Islamic Values and Ethics into Government}

The Muslim ummah, including its governance element and citizens, should be considered as an organic integrated whole since Prophet Muhammad [pbuh] described the "believers" as "like one body; if the head is in pain, the whole body suffers and if the eye is in pain, the whole body suffers" ${ }^{63}$ This corresponds to the nature of a systems management approach since it "views the organisation as a unified, purposeful system composed of interrelated parts. This approach gives managers a way of looking at the organisation as a whole and as part of a larger external environment. In so doing, systems theory tells us that the activity of any segment of an organisation affects in various degrees, the activity of every other segment". ${ }^{64}$

The Islamic government model is value-centred with the fundamental principle being Tawhìd. The main values to be inculcated were described earlier. The Value-Centred Islamic Management Model developed by Naceur Jabnoun (Figure 1), includes features that could be admirably adapted to an Islamic Government Model: "All the practices of strategic planning, decision-making, human resources management, leadership and systems and structures are chosen based on the extent to which they serve the Islamic values." ${ }^{65}$ 
Figure 1: Islamic Management Model (Naceur Jabnoun, 2012)

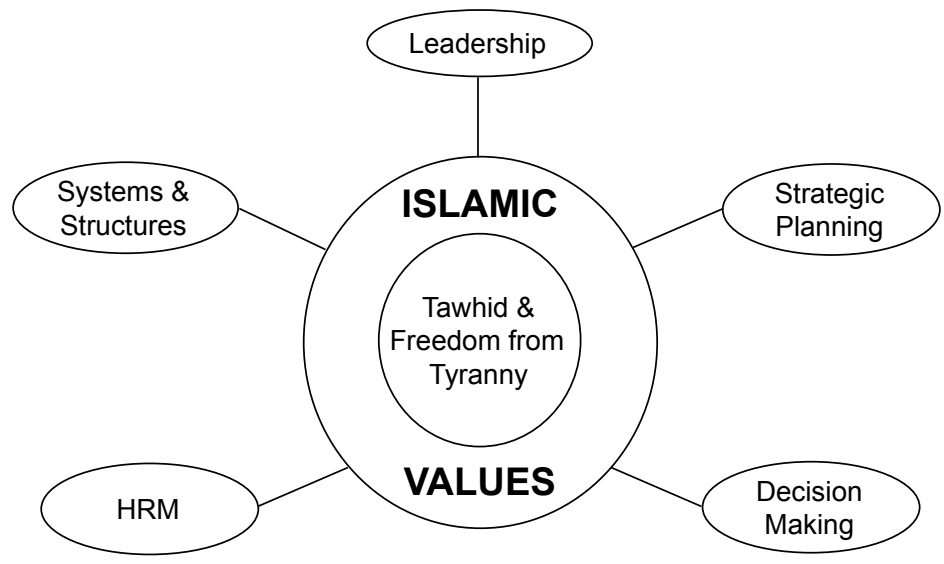

The manner in which these values can be integrated into governance is well shown by the Khulafä' ar-Rāshidūn. With expansion in the size of government in modern times, it is proposed that in addition to the country's leader taking the lead in the process, it is also recommended that a special unit be established and empowered so as to guide efforts for the inculcation of Islamic values throughout the government, public service, and national institutions.

Four levels of integration of values into the fabric of government can be considered:

1. Integration into the three organs of government - the executive, legislature, and judiciary, and subsidiary institutions.

2. Integration into all ministries and the Public service.

3. Integration into political parties that call themselves "Islamic".

4. Dissemination to the Public at large.

The Executive, Legislative and Judicial branches would have or should develop their own Islamic Values and Ethics Committee. Senior Judges are often chosen in a process that involves either or both of the Executive or Legislature branches of government where their credentials are vetted. As an example and consequence of the need to re-establish public confidence in the Kenyan Judiciary after a period when the Executive stamped his command over outcomes, the Judiciary seeks its transformation within a new framework that incorporates the ethical values of the rule of law, human dignity, equity, social justice, human rights, transparency and accountability ${ }^{66}$. Elimination of unethical practices was to be achieved by revising the Judiciary Code of Ethics while values and ethics will be accentuated through regular training and internal communications. 


\section{Public Service}

A number of examples exist in the government departments of Western countries, which could be modified for the inculcation of Islamic values in Muslim countries. Within each department, region, branch or agency there should be a designated committee or division responsible for the implementation of government policies on Islamic values. Useful general principles are cited below, following the OECD Council Recommendation on Improving Ethical Conduct in the Public Service of member countries, as adopted on 23 April $1998^{67}$ :

1. Ethical standards for the Public service should be clear and reflected in the legal framework.

2. Ethical guidelines should be available to public servants, especially in their interactions between the public and private sectors.

3. Political commitment to ethics should reinforce the ethical conduct of public servants.

4. The decision-making process should be transparent and open to scrutiny.

5. Managers, management policies, procedures and practices should promote ethical conduct.

6. Public service conditions and human resource management should promote ethical conduct.

7. Adequate accountability mechanisms should be in place within the public service.

In one relevant example, the Canadian Government identified Key Leadership Competencies that must be satisfied together with "effective behaviours" for positions at Deputy Minister to Supervisor level within the Public Service. ${ }^{68}$ Their approach involves a foundation of ethical values from which Public Service leaders deliver results through strategic thinking, engagement and management excellence.

A highly apt modern example relevant to developing an Islamic values program in the Public Service of Muslim countries is provided by the Canadian Public Works and Government Services Department (PWGSC) published as "Integrating values and ethics in the organizational culture". ${ }^{69}$ A Senior Departmental Ethics Counsellor was first appointed to champion the initiative. In 1999 the Ethics Development Office (EDO) was established as "a small office designed to assist employees, sectors and branches by providing information so they could incorporate ethical considerations into their approaches, plans and strategies." To secure buy-in from senior management and provide a forum to discuss how values impact at work, an Ethics Leadership Team comprising executives from across the branches and regions was also established. Ethics Officers were appointed and report to three core staff responsible respectively for 
policy and communications, training, and case management. These staff members act as service providers giving functional advice and assisting in developing and implementing ethics action plans, and in building awareness.

\section{Civil Society}

A multifaceted approach is needed to inculcate Islamic values into civil society. The government has some institutions that can influence civil society, but in the main, civil society has the freedom to accept the Islamic values or ignore them. The Home Affairs Ministry would have an oversight role to ensure that Islamic values are promoted in the national media, such as newspapers, television, and the print media. Government Islamic Affairs Departments can disseminate positive messages on Islamic values, such as in Friday khutbahs in masjids and in the curricula taught in madrassahs. The Ministry of Education would have a similar role in schools and tertiary institutions.

An admirable effort to incorporate "religious and spiritual values" into national governance in a multi-religious society has been provided by initiatives of former Prime Minister of Malaysia, Abdullah Haji Ahmad Badawi. In addition to implementing the Prime Minister's Directive No. 1 of 1998, which aimed to enhance the integrity of government administration in all ministries, departments and agencies of Federal and State governments, Badawi formulated a National Integrity Plan (NIP), as a master plan to guide similar implementation among other sectors such as the private sector, political parties, non-governmental organisations, religious groups, the media, women, youth and students in an integrated manner. It was addressed to all citizens, Muslim and non-Muslim alike:

The formulation of the NIP is predicated upon the spirit and principles of the Federal Constitution, the philosophy and principles of the Rukun Negara as well as the aspirations of Vision 2020. The overall objective of the NIP is to fulfil the fourth challenge of Vision 2020, namely, "to establish a fully moral and ethical society whose citizens are strong in religious and spiritual values and imbued with the highest ethical standards. ${ }^{70}$

The initial target, Target 2008, involved five priorities, namely:

- Effectively reduce corruption, malpractices and abuse of power;

- Increase efficiency of public delivery system and overcome bureaucratic red tape;

- Enhance corporate governance and business ethics;

- Strengthen the family institution; and

- Improve the quality of life and people's well-being. 
The approach and overall strategy of the NIP is to mobilise all sectors of society to support and uphold the aspirations of the NIP, and to cooperate and coordinate their activities to implement its various programmes - from the grassroots to the highest societal levels. Its synergy is to involve institutions 'from below' with those 'from above' to generate its own "dynamism and vitality". This is a unique initiative of the Malaysian government through its championing organisation, the Institute of Integrity Malaysia. One informed United States-based blogger was "very impressed" with the Malaysian NIP and opined that "many countries and organizations can use that plan as a model" ${ }^{71}$

\section{Change Management}

One critical management competence required for the task of integrating Values in governance is change management. Western specialists opined: "when a group undergoes a change, it is not the organisation that changes, but rather the behaviours of individuals" 72 - completely in line with Qur'anic advice that:

Allah will not change the condition of the people until they change what is within themselves. $\left(A l-R a^{\prime} d, 13: 11\right)$

Prophet Muhammad [pbuh] was probably the ultimate change manager in history and his teachings as a consequence of his exemplary character continue to influence millions today towards good. His was a transformational leadership style - inspiring positive change in each of his followers with concern for their individual well-being.

\section{Continuous Improvement towards Excellence (Ihsan)}

I $h \bar{a} \bar{a}$ means not only perfecting one's own 'ibādah to please Allah, but to excel in all of one's worldly endeavours - worship, work and social interactions. This is in accordance with the hadith: "Allah the Almighty wants that when one of you does a job, you do it well". ${ }^{73}$ In terms of government, it means inculcating Islamic values into governance with continual improvement towards the ideal.

As circumstances continually change an organisation must aspire to continuous improvement. New governments are elected and chief decision-makers in government departments come and go. The external environment also changes due to factors such as macroeconomic and political changes and availability of new technologies. Consequently, a government must continually transform itself within the bounds of the constitution to deliver on its mission. ${ }^{74} \mathrm{~A}$ continuous improvement model shown in Figure 2 for improving the performance of a government agency comprises five stages. After obtaining Senior management commitment (Step 1), Planning is conducted (Step 2), leading to Implementation of a Program (Step 3), with its performance then Measured and Evaluated 
(Step 4), and the Program finally Reviewed to assess whether its objectives and targets are being met, which leads to continuous improvement proposals from Management (Step 5) for further implementation.

Following Islamic teachings, the core principle of continuous improvement is the individual's self-reformation (tazkiyyah) and all are encouraged to continually seek to improve their own performance towards excellence (ihssān). Training can be provided to help personnel in self-reflection and to solve root causes of problems. Furthermore, small sustained steps are encouraged for long-term improvement rather than large steps that may not be sustainable over the longterm. Prophet Muhammad [pbuh] advised: "The best loved deeds to Allah are the ones that are continuous even if they are not very many." 75

Figure 2: Continuous improvement model for a government agency. ${ }^{76}$

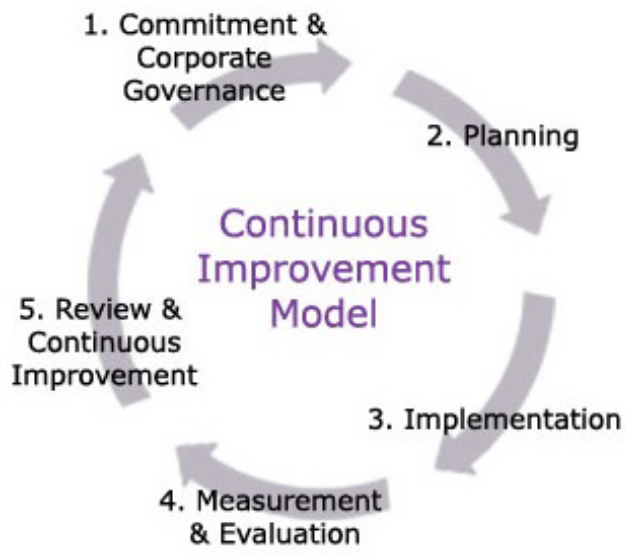

\section{Conclusion}

The important Islamic principles and values elucidated in the article are aligned with maqāssid al-sharī'ah objectives. Means are outlined for implementing these in governance and civil society. A Systems management approach is the most appropriate manner in which the Islamic values can be integrated effectively into the framework of governance.

\section{Policy Recommendations}

- Muslim governments should stress on reform starting with individuals using Tazkiyah and Tafakkur, and by government based on an Ișlāh-Tajdìd approach, to incorporate Islamic values into society. 
- Muslim countries should stress the foundation of Islamic values in developing leadership competence in the Public Service and to implement a program of integrating values, based on successful models such as that of the Canadian Public Works Department. Efforts should be made to ensure continuous improvement towards excellence. All practices of strategic planning and decision-making, and systems and structures should consider the extent to which they serve Islamic values.

- Muslim countries should consider adopting themselves the approach of the National Integrity Plan of Malaysia as a means of integrating Islamic values and ethics into their civil societies.

- The importance of Islamic principles and values should be taught in schools, and research conducted to facilitate implementation of these into government and civil society.

\section{Notes}

* Daud Abdul-Fattah Batchelor, an Australian scholar, is Associate Fellow at IAIS Malaysia. He has a broad experience in industry, academia and international con $\urcorner$ sulting covering the fields of Environmental Management, Islamic Political Sci־ence and Earth Sciences. He has been active in Muslim community organisations and is co-founder of the Islamic College of Brisbane. Daud has an MA in Islamic and Other Civilisations from ISTAC, and was presented the Longmans Award for $\mathrm{PhD}$ research at Universiti Malaya. He has an MSc from the Imperial College of Science and Technology, London and a Master of Engineering Science. He is currently working at assisting the Afghanistan peace process by determining how differences may be resolved to achieve a workable political framework, in the context of his current research focus on Islamic political systems. (Email: daud.batchelor@iais.org.my)

1. Daud AF Batchelor, "A New Islamic Rating Index of Well-Being for Muslim Countries", Islam and Civilisational Review, Vol. 4 (2), April 2013, Table 3.

2. Olivier Roy, Afghanistan: From Holy War to Civil War (Princeton, NJ: Darwin Press Inc, 1995), pp. 57, 112.

3. Oliver McTernan commented in "Is the spirit of the Arab Spring dead?", MENA Insights, vol. 01 (01), May 2014, p.37: "There are a number of studies which show that without institutions that guarantee the dignity and rights of the individual and the principles of justice, there will always arise the possibility of the derailment of a nascent democracy from the elements of the so-called 'deep state'.

4. Al-Qur'an 3:110.

5. "Change management" as a specific discipline began to develop in the 1980s supported by leading western corporations with input from engineers and psychologists in developing programs such as Total Quality Management (TQM).

6. The word "System" derives from the Greek word systēma meaning "whole compounded of several parts“. Its use goes back to Philosophers Plato (Philebus) 
and Aristotle (Politics). As a useful paradigm it has been developed especially by western scientists from the 19th century, while "Systems thinking" developed in the early $20^{\text {th }}$ century by biologists and engineers. Refer however to the hadith where Prophet Muhammad [pbuh] described the Ummah as a body with separate interacting parts, displaying his advanced understanding of "Systems thinking".

7. Ismail R. al-Faruqi and Lois Lamya al-Faruqi. "The Essence of Islamic Civilisation".<http://i-epistemology.net/ismail-faruqi/161-the-essence-ofislamic-civilization.html> (Accessed 19/01/2014).

8. Yusuf al-Qaradawi in Min fiqh al-dawlah fi 'l-Islam (Cairo: dar al-Shuruq, 1417 AH/1997), p. 130-47, stated something similar: "we are entitled ... to take from other ideas and methods that benefit us and do not, in the meantime clash with a clear and unequivocal text".

9. Nayef Al-Rodhan, Sustainable History and the Diginity of Man: A Philosophy of History and Civilisational Triumph (Berlin, LIT, 2009).

10. Al-Qur'an 4: 59, 12: 40.

11. Al-Qur'an 2: 30; 38: 25-26.

12. Mohammad Hashim Kamali, "Civilian and Democratic Dimensions of Governance in Islam” Al-Shajarah, Volume 9(2), 2004, pp. 130-131.

13. Such as al-Marawadi, Abu Hamid Ghazzali, Ibn Tamiyah, and Ibn Khaldun.

14. Mohammad Hashim Kamali, Constitutionalism and Democracy: An Islamic Perspective, Islam and Civilisational Renewal, Vol. 2 (1), 2010a, p 23.

15. Mohammad Hashim Kamali, Freedom, Equality and Justice in Islam (Petaling Jaya, Malaysia: Ilimiah Publishers, 2002a), p. 107.

16. Refer for example: Muhammad Salim El-Awwa. On the Political System of the Islamic State, trans. by Ahmad Naji al-Imam and Anwar Beg (Indianapolis: American Trust Publications, 1980), p. 98.

17. Kamali, 2002a, p. 110.

18. Al-Bukhari, Vol. 2, p.138.

19. Kamali, 2002a, p. 109.

20. Tawfiq al-Shawi, al-Mawsu'ah al- 'asriyyah fi 'l-fiqh al-jina'i al-islami (Cairo: Dar al-Shuruq, 1421 AH/2001), 1, p. 106.

21. Muhammad Asad, The Principles of State and Government in Islam (Gibraltar: Dar Al-Andalus, 1980), p.88.

22. At-Tirmidhi, no. 659; On authority of Fatimah bint Qays.

23. Kamali, 2010a, pp. 18-45.

24. Muhammad Assad, p.52; El-Awwa, p. 96.

25. Kamali, 2010a, p. 36.

26. Al-Bukhari, Book 89, Number 251; narrated by Abu Hurairah.

27. Mohammad Hashim Kamali, "The Ruler and Ruled in Islam: A Brief Analysis of the Sources". Conference paper presented in Kuantan, Malaysia, October 2002b.

28. Al-Bukhari, Book 89, Number 252.

29. Kamali, 2011, pp. 195-196.

30. El-Awwa, p.119.

31. Kamali, 2004, p.141.

32. Kamali, 2010a, p. 31.

33. Kamali 2010a, p. 31.

34. Kamali, 2002a, p. 47. 
35. Kamali, 2002a, pp. 49-50, 60.

36. Mohammad Hashim Kamali, The Dignity of Man: An Islamic Perspective (Cambridge, UK: Islamic Texts Society, 2002c), p. 1.

37. Sahih Muslim, Book 20, Number 4546.

38. Daud AbdulFattah Batchelor, "Renewal and Reform for a Post-Karzai Afghanistan: A Critical Appraisal of the 2004 Constitution", Islam and Civilisational Renewal, Volume 5(1), January 2014, P.37.

39. Mohammad Hashim Kamali, Citizenship and Accountability of Government: An Islamic Perspective (Cambridge, UK: Islamic Texts Society, 2011), p.159.

40. Ahmad Bello Dogarawa, "Hisbah and the promotion of ethical business practices: A reflection for the Shariah implementing states in Nigeria", International Journal of Islamic and Middle Eastern Finance and Management, Vol.6 (1), pp. 51-63.

41. For example, Constitutions of Algeria, Egypt, Iran, and Pakistan cite the general requirement of freedom of expression, which is applicable to the media.

42. Anup Shah, "Media in the United States", 12 January, $2012<\mathrm{http}: / /$ www. globalissues.org/article/163/media-in-the-united-states> (Accessed 23/03/2014)

43. Al-Qur'an 2: 188.

44. Kamali, 2004, p. 142.

45. Mohammad Hashim Kamali, The Right to Life, Security, Privacy and Ownership in Islam (Petaling Jaya: Ilmiah Publishers, 2013), p.74.

46. Sunan Abu Dawud, Hadith 1595.

47. Mohammad Hashim Kamali, "Bribery and Corruption from an Islamic Perspective", IAIS Bulletin, Nos. 10 and 11, September-December 2012, p. 10.

48. Mohammad Hashim Kamali, Moderation and Balance in Islam: The Qur anic Principle of Wasatiyyah (Subang Jaya, Selangor: Ilmiah Publishers, 2010b), p.5.

49. Mohammad Hashim Kamali, The Middle Path of Moderation in Islam: The Qur'anic Principle of Wasatiyyah [Oxford: Oxford University Press, 2014] (In manuscript).

50. Musnad Ahmad, 3/479.

51. Al-Qur'an, 96: 1-5.

52. Al-Suyuti, Al-Jami' al-Saghir, II, 527, hadith 8956. On authority of Anas bin Malik.

53. Abdul Rashid Moten, Political Science: An Islamic Perspective (New York: St Martin's Press, 1996), p. 42.

54. Kamali, 2014, p.118.

55. Narrated by at-Tirmidhi, no. 2422.

56. Esposito, John L, "Islam: Ideology and Politics in Pakistan," in The State, Religion, and Ethnic Politics: Afghanistan, Iran and Pakistan, edited by 'Ali Banuazizi and Myron Weiner (Syracuse, NY: Syracuse University Press, 1986): 364.

57. Mumtaz Ahmad, "Islamisation and Sectarian Violence in Pakistan", Intellectual Discourse, vol. 6 (1), 1998: pp. 11-17:34.

58. Sumaya Mohamed and Shadiya Baqutayan, "Toward Social Change in Islam", International Journal of Basic \& Applied Sciences, Vol. 11 (2), April 2011, p. 23-33.

59. A Muslim is a person who follows the religion of Islam; a mu'min is a Muslim who truly believes in Allah and His Messenger in his heart and endeavours to 
practice as a sincere Muslim; a muhsin is a mu'min who has perfected his belief, practices and sense of slavehood to Allah.

60. B. Lewis and Others, The Encyclopaedia of Islam (Leiden: E.J. Brill, 1991), p. 538.

61. Sumaya and Baqutayan, 29.

62. Mohammad Hashim Kamali, "Tajdid, Islah and Civilisation Renewal in Islam”, Islam and Civilisational Renewal, Vol. 4 (1), October 2013, 488.

63. Al-Bukhari, no. 6011. Narrated by Nu'man Ibn Bashir.

64. James Gibson, John Ivancevich, Robert Konopaske, Organizations (Columbus, OH: McGraw Hill, 2011), p. 30.

65. Naceur Jabnoun, Islam and Management (Riyadh: International Islamic Publishing House, 2012), p. 347.

66. Government of Kenya, Judicial Transformation Framework 2012-2016. <http:// www.judiciary.go.ke/portal/assets/downloads/reports/Judiciary\%27s\%20 Tranformation\%20Framework-fv.pdf $>$ (Accessed 12/01/2014).

67. OECD, Principles for Managing Ethics in the Public Service (OECD Public Management Service, May 1998), PUMA Policy Brief No. 4. <http://www.oecd. org/gov/ethics/1899138.pdf> (Accessed 12/01/2014)

68. Canada Public Service Agency and the Public Service Commission, Key Leadership Competencies, $2006<\mathrm{http}$ //www.tbs-sct.gc.ca/tal/kcl/dwnld/klceng.pdf $>$

69. Public Works and Government Services Department, Canada, Integrating values and ethics in the organization culture <http://www.tbs-sct.gc.ca/rp/sgs05-eng. asp $>$ (Accessed 25/11/2013).

70. Abdullah Haji Ahmad Badawi, National Integrity Plan <http://www.pmo.gov. my/dokumenattached/Dasar/NIP.pdf $>$ (Accessed 14/01/2014).

71. Frances Chu's Blog, The National Integrity Plan of Malaysia. <http:// franceschusblog.blogspot.com/2013/09/the-national-integrity-plan-of-malaysia. html $>$ (Accessed 14/01/2014)

72. National Association of State Chief Information Officers (NASCIO), Transforming Government through Change Management: The Role of the State CIO, p. 7. <http://www.nascio.org/publications/documents/NASCIOTransforming\%20Govt-Research\%20Brief.pdf $>$ (Accessed 14/01/2014).

73. Sunan Al-Bayhaqi, no. $7 / 233$.

74. NASCIO, p.1.

75. Al-Bukhari, Book 76, Number 469; narrated by A'isha (RA); also in Sahih Muslim.

76. Australian Public Service Commission (2007), Agency Health: Monitoring Agency Health and Improving Performance. <http://www.apsc.gov.au/ publications-and-media/archive/publications-archive/agency-health $>$ (Accessed 14/01/2014). 